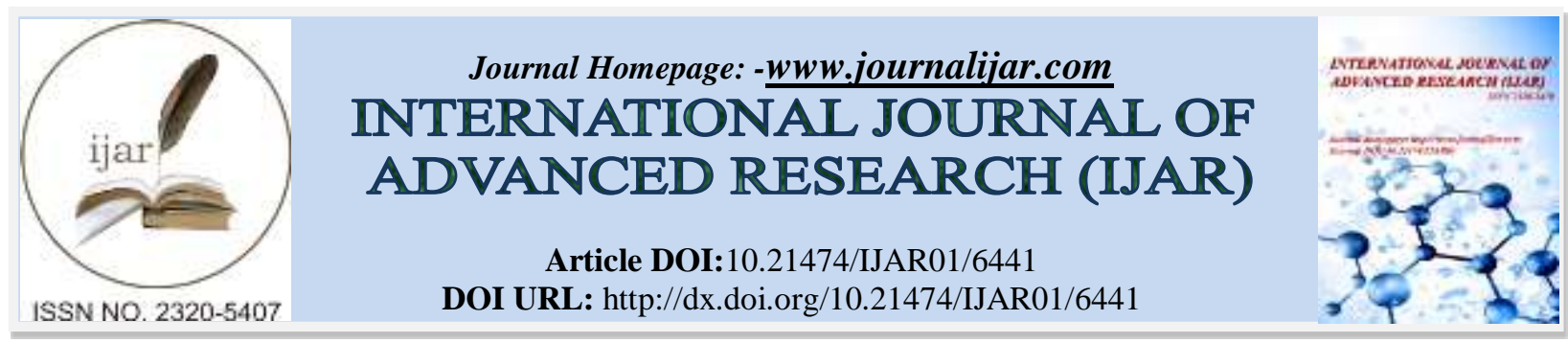

RESEARCH ARTICLE

\title{
PERCEPTION OF ENGLISH LANGUAGE TEACHERS ON USE OF LIFE-STAGING TECHNIQUE DURING ENGLISH LANGUAGE TEACHING IN PUBLIC SECONDARY SCHOOLS IN WARENG SUB- COUNTY, KENYA.
}

Lydia Jebichii, Situma, Julia and Justina Ndaita.

Kisii University, Faculty of Education and Human Resource Development, Eldoret Campus.

\section{Manuscript Info}

Manuscript History

Received: 04 December 2017

Final Accepted: 06 January 2018

Published: February 2018

Keywords:-

Perception, Life-Staging, Teachers, Technique.

\begin{abstract}
Life-staging of set-books is employed by language teachers as one of the teaching technique. Not all teachers employ life-staging in their lessons since there are some challenges on its usage. The purpose of this study is to establish the Perception of English Language Teachers on Use of Life-Staging Technique During English Language Teaching in Public Secondary Schools in Wareng Sub-County, Kenya. A descriptive survey design was adopted. Research was both qualitative and quantitative; interviews and questionnaires were used to collect data. Research instruments were tested for validity and reliability. A sample size of 433 respondents comprising of 384 students, 32 teachers of English language and 16 HODs language department was drawn from 16 public secondary schools to participate in the study through quarter, purposive and stratified random sampling techniques. In this study, descriptive statistics was used to analyze data where the percentages and frequency distribution tables was used to give summary of the findings. The data collected was analyzed using the Statistical package for Social Science (SPSS). The study found out that teachers had a positive attitude towards use of life staging technique. The study recommended that teachers of English needed to use learnercentered approaches like life-staging technique since the strategy improved on learning outcomes. The findings of this study will help education stakeholders and policy makers to come up with better teaching techniques that will suit English as a second Language classroom and improve English language performance in secondary schools.
\end{abstract}

Copy Right, IJAR, 2018,. All rights reserved.

\section{Introduction:-}

There are several teaching methodologies that teachers of English can choose from. Amongst them is life-staging technique. Actively engaging students in a life-staging technique during English learning process is a powerful tool. It improves students' confidence, creativity and motivation in learning. While achieving the teaching goals, action and entertainment is combined through the use of life-staging technique hence making the learning process enjoyable (Moseti, 2007). Teachers of English have different perception towards this technique while others may be lacking knowledge and skills on how to use it. Since this life-staging technique is the appropriate and effective 
method of teaching as stated by Jeruto (2006), this study sought to find out the challenges on its usage in English language teaching in public secondary schools, as the above scholar did not do so.

Teaching English as a foreign Language engages different methodologies, although some of them are commonly used, Maig (2014). Among these methodologies is Drama and life-Staging (sub-set of theatres). Since drama and theatre have a close relationship, it is important to define them. Maig (2014) makes a comparable indication explaining that in the perspective of teaching drama, the difference between drama and theatre can be seen in the way it is professed. It is obvious that theatre plays the same role with drama. In educational theatre, the learners are the audience hence this makes it clear that classroom drama and educational theatre plays the same role, and are appropriate and effective teaching methods.

In reference to Nawi (2014) on applied drama in English, Staging the textbook is a major teaching methodology, where distillation method is used for the teaching programme in the textbook section, and the explanation focuses of the language themes; skills and vocabulary to be learnt are extracted and identified. These distilled elements are matched with a layer of drama and then staged above the textbook unit, integrating, context -setting opportunities, potential for complication or tension, potential for a story as well as the target language elements. The whole process is as shown below.

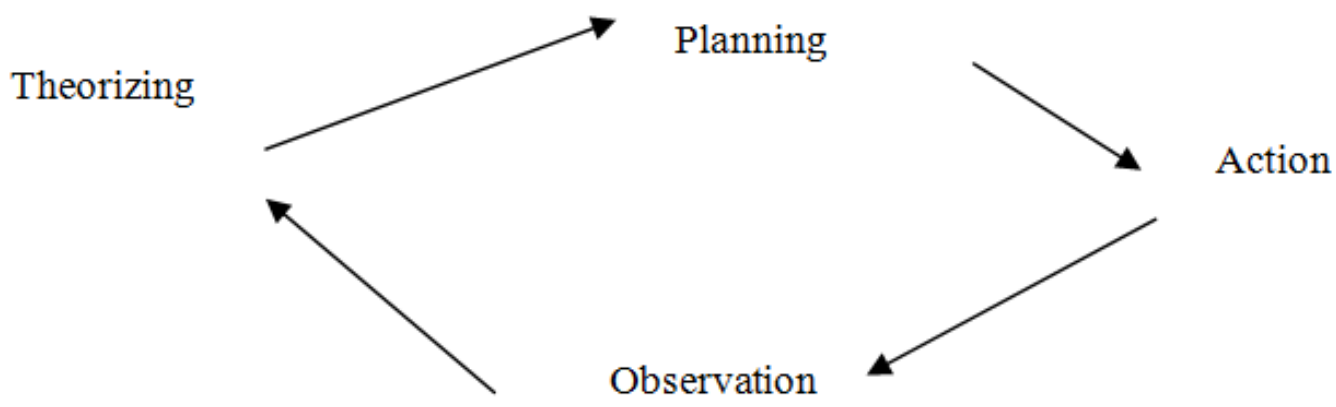

Source: Nawi (2014)

This shows that for a teacher to use life-staging technique he/she must have mastered on knowledge and skills on the same so as to be effective, and enough time is required for preparation. Similarly, Moore (2012) asserts that theatre or drama is used by teachers in England and Wales and also in South Hunsley School in U.K. According to him the personal development of a student is as result of the role drama plays. Students get to explore experiences and issues in a supportive and safe environment due to stimulated imagination by drama. Regardless of academic ability, theatre provides students with the sense of achievement that promote self-esteem. Moore did not find out the challenges facing usage of life-staging technique hence there is need for other research to do it. Stinson (2009) posits that Drama in Singapore is seen as one of the most important English language teaching methodology. This shows that life-staging technique is the most effective and appropriate method of teaching English as the second language. This study therefore aimed at finding out the perception of English language teachers on use of life-staging technique during English language teaching in public secondary schools in Wareng Sub-County, Kenya Mutai (2012) on an assessment of the teaching strategies employed by English language teachers in Eldoret municipality, posits that in 1990's and the proceeding years, poor proficiency of English language by Kenya's students in secondary schools turned on to draw attention on learning and teaching of English language. Barasa (2005) identified various instances recorded that emphasized this concern. According to the research by Gudu (2010), the importance of instructional methods is determined by the right teaching method that result to the quality results given that they act as a link in the total learning and teaching chain. This scholar did not categorically asses the challenges facing usage of life- staging of set -books on English language teaching which this study seek to do so.

Since almost all the school subjects are taught in English language, English Language plays a strategic and central role in the school system. However, the content is inadequate for the students to acquire requisite skills for the give and take of social experience and for better performance in their examinations (Jeruto, 2006). Such skills (reading, writing, listening and speaking) may be acquired through the use of life-staging of compulsory set-books. Effective teaching of English language is as a result of applying learner friendly teaching methodology. This study therefore aimed at finding out the extent to which life-staging technique is applied in teaching English set-books in public secondary schools as the above scholar did not. 
The Kenya National Examination Council annual reports of 1998; 1999 and 2006, indicated that there was a crisis in the teaching of English language in secondary schools, which has led to poor performance. Kemboi and Osman (2015) view the result of this as teachers using teacher-centered methods of instruction than learner centered. They argued that life-staging technique is the most appropriate methodology that teachers of English have to employ so as to be effective. Mutai (2012) blames teachers on poor performance in English language due to the use of teachercentered methods of instruction. In Wareng Sub-County, performance in English language is low as compared to other subjects. To improve on students' performance in the subject, Mutai views life-staging technique as one of the learner-centered methods that needs to be used by teachers of English language. However, the researcher did not draw light on the issue of perception of teachers towards the use of life-staging technique as a medium of instruction. This study therefore sought to determine the Perception of English Language Teachers on Use of LifeStaging Technique During English Language Teaching in Public Secondary Schools in Wareng Sub-County, Kenya.

\section{Literature Review:-}

Many names have been used in teaching English language in dramatic activities for instance drama activities, drama techniques, creative drama activities. Nevertheless, the integration of various activities is by the sub characteristics of drama activities by using improvisation, mime, story-telling, simulation, role-plying, dramatization, language games (Stinson, 2014). According to classification of Maley and Duff, (2001) on drama activities, learners are provided with the opportunity to employ their personal characters in speaking skill; role-playing through imagination, gestures, memories, facial expression, and potential experience in the past to act the roles assigned. Philips (2003) also mentioned that dramatic activities, will aid in reinforcing individuals in developing their communicative skills, if the teachers know how to utilize them effectively, though the dramatic activities are only the role plays.

Punyaruang (2012) studied the Creative Dramatic Activities to advocate students' writing and speaking skills for Classical Dramatic Arts college students in Angthong Province. She found that students were more motivated in learning as their speaking skill was higher than the setting criteria. Jaiharn (2003) on comparison and study of ability to speaking English by using dramatic activities of seventh grade students at Barn Yang Tia School in Surin found that the use of dramatic activities by the students in studying the language enabled them to speak Furthermore, dramatic class students were highly motivated than the non-dramatic class. Stinson (2014) studied the dramatic activities with the eleventh-grade students of Yasothorn Province and discovered significant improvement in students speaking abilities.

Thousands of candidates watch stage adaptations of literature set-texts to prepare themselves for examinations during their holidays (Karengo, 2007). According to Karengo, the trend continued in the year 2008 with dozens of groups staging the English and Kiswahili literature books at various venues. Since this was carried out by private groups, this study aims to find out whether teachers have enough skills and knowledge on life-staging technique that will enable them use it in the classroom as a teaching methodology.

Life-staging of set books in secondary schools psyches the learners to be interested in English language. In support of this, Khaemba, (2014) quotes the Chinese proverb "tell me and I will forget show me and I will remember, involve me and I will understand". life-staging strategy is important in stimulating creativity of the students in problem solving. It can challenge students' perception about their world and themselves.

The use of life-staging technique in English language teaching is advantageous because it makes teaching a studentcentered activity. Teachers of English are free to choose teaching techniques that will enable them achieve the set objectives. Baker (1992) cited in Kemboi and Osman (2015) argues that attitudes are crucial in language growth or decay, restoration or destruction. The status and importance of a language in society and within an individual derives largely from adopted or learned attitudes. Attitude is something an individual has, which defines or promotes certain behavior. An attitude is a hypothetical psychological construct, it touches the reality of language life.

Kemboi and Osman (2015) in their study also stresses the importance of attitude in bilingualism. Attitudes are learned disposition, not inherited and are likely to be relatively stable; they have a tendency to persist. However, attitudes are affected by experiences thus attitude change is an important notion in bilingualism. Attitudes vary from favourability to unfavorability and are complex construct, that is they may be both positive and negative feelings attached to a language situation. The above scholars did not find out perception of language teachers towards drama 
activities hence this study aimed at addressing the perception of English language teachers towards life- staging technique as a method of instruction.

Baldwin, (2012) on using educational drama and role- play in teaching English in Gaza Governorates postulates that teachers of English recognize the important role drama activities plays in engaging learners in understanding the exploration of text. Drama also develops learner's skills in analyzing characters, themes and ideas, in the language literacy techniques and authorial view point. Planned drama approaches develop learner's critical analysis and creativity which embed the appropriate structures, processes and skills to create personal responses, which are then transferred when analysis of new texts, ideas and situation are required. Baldwin, (2012) points out teachers as having positive attitude towards the use of drama as a teaching methodology. The above study did not work on the perception of teachers towards life-staging as it is another subset of theatre. The study did not also analyze the challenges facing usage of life-staging on English language teaching. This study therefore sought to address the perception of English language teachers on life- staging as a teaching technique and challenges facing usage of lifestaging on English language teaching.

Sulaiman (2013) examined the perception of teachers towards life-staging technique, in ESL in Palestine. He found that there was a significant difference about teacher's perception on the use of drama techniques depending on their gender, experience, institution to which they belong and on their qualifications. The study did not examine the challenges facing usage of life-staging technique on English language teaching. This study therefore sought to examine the challenges of usage of life- staging (sub-set of theatre) on English language teaching and the perception of teachers towards this technique.

\section{Research Methodology:-}

In this study, a descriptive survey research design was employed. Orodho (2009) pointed out that descriptive survey is a method of collecting data, interviewing or administering questionnaires to a sample of individuals. The study targeted 1280 Form three and four students, 106 teachers of English and 53 heads of languages department from 53 secondary schools in Wareng Sub-county, Kenya. Since all the 53 public secondary schools in Wareng Sub-County were not going to be covered adequately within the given time, a sample was used which consisted of 16 schools, which is the $30 \%$ of the 53 public secondary schools in the region. Kothari (2008), states that a representative sample of the entire population is $30 \%$. In this case therefore, 16 public secondary schools were sufficient representative for the study estimation. Since other schools had more than one stream, the study sampled only one stream in form three and four, with one English language teacher for uniformity. A total number of 16 HODs languages department, 32 English language teachers and 384 students formed the study sample.

All the public secondary schools in Wareng sub-county were stratified into two divisions; Kesses and Kapseret. Quota random sampling was used to select 11 schools in Kesses and 5 schools in Kapseret division from the 16 public secondary schools which were selected in Wareng Sub County. Quota sampling ensured that each Stratum was assigned the proportionate number of schools in the sample as in the population. In selecting schools for study in each stratum, codes were used to identify them. The researcher ensured that each school had a unique code for its identity. Stratified simple random sampling was used to ensure that each school in each stratum has an equal chance to be included in the sample.

Purposive sampling technique was used to select the school H.O.Ds languages from all the 16 selected schools and form three and four teachers of English language. H.O.Ds languages, teachers of English and form three and four students are included in this study because HOD's are in charge of language or departmental pedagogies while students are the recipients hence all have knowledge on issues revolving around pedagogies of set-books.

This study used questionnaires, document analysis and interviews to collect primary and secondary data in public secondary schools in Wareng sub-county Uasin- Gishu County. The questionnaire was administered to 384 students and 32 language teachers from the 16 selected schools. Data collected from the questionnaires was in likert scale and also open-ended questions illustrating relative opinion from the respondents. The interview schedule was designed for the sixteen (16) HODs of language departments from each of the 16 selected schools. The interview was conducted through discussions using a set of open- ended questions to find out the relative opinion from the respondents on life-staging technique. This enabled the researcher to obtain qualitative data that the questionnaires might not have captured. 
In ensuring the validity of the research instruments, the researcher consulted supervisors, colleagues and experts in the Department of Curriculum and Instruction who helped in determining whether the items in the instruments solicited relevant information. Their suggestions and clarifications were used to improve on the instruments. The experts also examined the validity of the measuring instruments as well as the adequacy (content validity). Their suggestions were used to improve on the instruments (construct validity). A pilot study was carried out in the nearby Nandi North Sub-County, using two secondary schools to ascertain the reliability of the instruments. The test re-test method was employed to test the reliability of the questionnaires. The coefficient obtained was then converted into an appropriate correlation for the entire test using the spearman and Brown prophecy formula. A correlation of more than 0.7 was considered appropriate to ascertain the reliability of the instruments since Orodho (2009) argues that reliability coefficient of 0.7 or more is appropriate to ascertain the reliability. In this study, a reliability coefficient of 0.76 was obtained on the questionnaires and therefore the instruments were considered reliable and therefore used for data collection.

Data from questionnaires were analyzed by use of frequencies and percentages. Descriptive analysis such as frequencies, percentages, mean and standard deviation was used to help understand and interpret variables distribution size and relationship. Qualitative data from interviews were analyzed and presented qualitatively by use of themes as per the research objectives.

Ethical issues adhered to during the study involved seeking for research permit from The National Commission for Science, technology and Innovations, informed consent, confidentiality of all the information by the respondents and acknowledgment of cited work.

\section{Results and Discussions:-}

The aim of this study was to establish the perception of English language teachers on use of life-staging technique on English language teaching in Public secondary schools in Wareng Sub-County Uasin-Gishu County. To achieve this objective, teachers were asked to rate their level of agreement on a five point likert scale items in the questionnaire as; Strongly Disagree (SD), Disagree (D), Undecided (UD), Agree (A) and Strongly Agree (SA). Their responses were tabulated and the Results are presented in Table1.

Table 1:- Responses on Perception of English Language Teachers on Use of Life-Staging Technique on English Language Teaching

\begin{tabular}{|c|c|c|c|c|c|c|c|c|c|c|}
\hline \multirow[t]{2}{*}{ Statement } & \multicolumn{2}{|c|}{ SD } & \multicolumn{2}{|c|}{ D } & \multicolumn{2}{|c|}{ UD } & \multicolumn{2}{|c|}{$\mathrm{A}$} & \multicolumn{2}{|c|}{ SA } \\
\hline & $\mathrm{F}$ & $\%$ & $\mathrm{~F}$ & $\%$ & $\mathrm{~F}$ & $\%$ & $\mathrm{~F}$ & $\%$ & $\mathrm{~F}$ & $\%$ \\
\hline $\begin{array}{l}\text { As a teacher of English, I rarely choose } \\
\text { life-staging technique for teaching } \\
\text { literature set-books due to limited time } \\
\text { scheduled for the lesson }\end{array}$ & 5 & 16.7 & 7 & 23.3 & 2 & 6.7 & 8 & 26.7 & 8 & 26.7 \\
\hline $\begin{array}{l}\text { Role play is enjoyable during the } \\
\text { teaching-learning process }\end{array}$ & 0 & 0.0 & 3 & 10.0 & 5 & 16.7 & 8 & 26.7 & 14 & 46.7 \\
\hline $\begin{array}{l}\text { Use of life staging enable help learners } \\
\text { to understand the exploration of the set- } \\
\text { text }\end{array}$ & 3 & 10.0 & 4 & 13.3 & 0 & 0.0 & 12 & 40.0 & 11 & 36.7 \\
\hline $\begin{array}{l}\text { Life staging develops learner's skills in } \\
\text { analyzing characters, themes and ideas, } \\
\text { in the language literacy techniques, } \\
\text { when I use it in teaching set-books }\end{array}$ & 0 & 0.0 & 5 & 16.7 & 0 & 0.0 & 5 & 16.7 & 20 & 66.7 \\
\hline $\begin{array}{l}\text { Students perform better in English } \\
\text { when English teaching is dramatized }\end{array}$ & 3 & 10.0 & 1 & 3.3 & 2 & 6.7 & 5 & 16.7 & 19 & 63.3 \\
\hline $\begin{array}{l}\text { Learners actively engage in learning } \\
\text { language and literacy skills when they } \\
\text { are taught using life- staging }\end{array}$ & 3 & 10.0 & 2 & 6.7 & 0 & 0.0 & 9 & 30.0 & 16 & 53.3 \\
\hline $\begin{array}{l}\text { I am confident when using life-staging } \\
\text { strategy as a means of teaching English }\end{array}$ & 3 & 10.0 & 2 & 6.7 & 2 & 6.7 & 10 & 33.3 & 13 & 43.3 \\
\hline $\begin{array}{l}\text { Life-staging technique is an efficient } \\
\text { way to make students communicate and }\end{array}$ & 6 & 20.0 & 4 & 13.3 & 0 & 0.0 & 10 & 33.3 & 10 & 33.3 \\
\hline
\end{tabular}




\begin{tabular}{|c|c|c|c|c|c|c|c|c|c|c|}
\hline be sociable & & & & & & & & & & \\
\hline $\begin{array}{l}\text { Life staging stimulate learners' } \\
\text { imaginations and practice their abilities } \\
\text { of communication and listening in an } \\
\text { enjoyable process }\end{array}$ & 3 & 10.0 & 5 & 16.7 & 2 & 6.7 & 7 & 23.3 & 13 & 43.3 \\
\hline $\begin{array}{l}\text { I prefer teaching English set-books } \\
\text { using life-staging technique since the } \\
\text { students understand better and are not } \\
\text { bored with the lessons }\end{array}$ & 0 & 0.0 & 5 & 16.7 & 0 & 0.0 & 16 & 53.3 & 9 & 30.0 \\
\hline
\end{tabular}

Table 1 shows that 8(26.7\%) teachers agreed with the statement that teachers of English rarely chose life-staging technique for teaching literature set-books due to limited time scheduled, $8(26.7 \%)$ teachers strongly agreed with the statement, 7(23.3\%) teachers disagreed with the statement and 5(16.7\%) teachers strongly disagreed with the statement while $2(6.7 \%)$ teachers were undecided on the statement. The study findings showed that majority (53.4\%) of the teachers of English believed that time scheduled for a lesson is not enough for them to prepare for life-staging of set-books, not considering the welfare of the learners. This is consistent with the findings of Kemboi and Osman (2015) who argued that teachers of English language relied on teaching techniques that favoured them at the expense of their students thus making students to perform dismally in National examinations.

Moreover, 14(46.7\%) teachers strongly agreed with the statement that role play is enjoyable during the teachinglearning process, $8(26.7 \%)$ teachers agreed with the statement and $5(16.7 \%)$ respondents were undecided on the statement while $3(10.0 \%)$ teachers were in disagreement with the statement. The study found that majority (73.4\%) of the teachers of English believed that role play was enjoyable during the teaching-learning process. Because role plays imitate life, it helps the students to develop real life speaking skills by imagining and assuming the roles where they create a pretend situation, and they pretend to be some different persons. This was found to be consistent with Zyoud's (2016) findings which pointed out that role play was a familiar technique that was usually applied in the classroom to improve the students' skills in English.

Similarly, $12(40.0 \%)$ teachers agreed with the statement that use of life staging enable learners to understand the exploration of text, $11(36.7 \%)$ teachers strongly agreed with the statement and $4(13.3 \%)$ teachers disagreed with the statement while $3(10.0 \%)$ teachers strongly disagreed with the statement. It therefore emerged that majority $(76.7 \%)$ of the teachers of English in secondary schools were of the view that use of life staging enabled learners to understand the exploration of text. According to Ulas (2008), Janudom and Wasanasomsithi, (2009), life-staging pedagogy provides authentic communicative environments for the learners, and life staging activities can be used to heighten learners' speaking ability.

In addition, 20(66.7\%) teachers strongly agreed with the statement that life staging develops learner's skills in analyzing characters, themes and ideas, in the language literacy techniques, $5(16.7 \%)$ teachers agreed with the statement while 5(16.7\%) teachers were in disagreement with the statement. From the responses, it emerged that majority (83.4\%) of the teachers of English in secondary schools believed that life staging develops learner's skills in analyzing characters, themes and ideas, in the language literacy techniques. This implies that through life staging learners are able to acquire the necessary skills in English and therefore improve on their performances. This was shown to be consistent with the findings of Ngaroga (2006) who argued that learning is a relatively permanent change in behaviour which comes as a result of practice of an activity. Therefore, life staging as an activity can bring a positive change in the acquisition of the four language skills in English; listening, speaking, reading and writing. Since most teachers viewed life-staging technique from a positive perspective, this shows that teachers of English have positive attitude towards use of life-staging technique in teaching English set-books.

Furthermore, 19(63.3\%) teachers strongly agreed with the statement that students perform better in English when English teaching is dramatized, $5(16.7 \%)$ teachers agreed with the statement, $3(10.0 \%)$ teachers strongly disagreed with the statement while $2(6.7 \%)$ teachers were undecided on the statement. The study findings showed that majority (80.0\%) teachers of English in secondary schools believed that students perform better in English when English teaching is dramatized. This shows that drama was an important part of teaching set-books as it improves the learning outcomes. This supports an earlier work of Brash and Warnecke, (2009), who pointed out that dramabased role play has positive effects on learners' communicative and affective skills as it stimulates the learners' 
authentic conversation and allows them to act in a framework, so they can overcome their fear of certain emotional, linguistic or social constraints.

In addition, 16(53.3\%) respondents strongly agreed with the statement that learners actively engage in learning language and literacy skills when they are taught using life staging, $9(30.0 \%)$ teachers agreed with the statement, $3(10.0 \%)$ teachers strongly disagreed while $2(6.7 \%)$ teachers disagreed with the statement. The findings showed that majority $(83.3 \%)$ of the teachers of English in secondary schools were of the view that learners actively engage in learning language and literacy skills when they are taught using life staging. This implies that through life staging techniques, learners are able to acquire the listening, speaking, reading and writing skills. Several researchers such as Royka (2002) and Zyoud, (2007) point to the benefits of drama such as bringing enjoyment to lessons and increasing students' positive learning experiences. Nevertheless, Gaudart (1990) claims that drama pedagogy is an extremely time-consuming approach. This therefore shows that through life staging students are able to improve on their learning outcomes.

It was found that, 13(43.3\%) teachers strongly agreed with the statement that they were confident when using lifestaging strategy as a means of teaching English, 10(33.3\%) teachers agreed with the statement, and 5(16.7\%) teachers were in disagreement with the statement while 2(6.7\%) teachers were undecided on the statement. From the responses, it can be shown that majority (76.6\%) of the teachers of English in secondary schools believed that they were confident while using life-staging technique as a means of teaching English. This is contrary to the works of Maig (2014) who pointed out that some teachers were afraid of using life-staging strategy as they did not feel confident using the strategy in class. It was difficult to persuade them to reverse the traditional style.

In addition, $10(33.3 \%)$ teachers strongly agreed with the statement that Life-staging technique is an efficient way to make students communicate and be sociable, 10(33.3\%) teachers agreed with the statement while 10(33.3\%) teachers were in disagreement with the statement. The study reported that majority $(66.6 \%)$ of the teachers of English believed that life-staging technique is an efficient way to make students communicate and be sociable. This is in agreement with Hinkel (2004) who states, "in an age of globalization, pragmatic objectives of language learning place an increased value on integrated and dynamic multi skill instructional models with a focus on meaningful communication and the development of learners' communicative competence" (p. 113). This shows that life staging as a technique improves on learners' communication skills.

In this study, 13(43.3\%) of the teachers strongly agreed with the statement that life- staging stimulate learners' imaginations and practice their abilities of communication and listening in an enjoyable process, $7(23.3 \%)$ teachers agreed with the statement, $8(26.7 \%)$ teachers were in disagreement with the statement while $2(6.7 \%)$ teachers were undecided on the statement. Majority $(66.6 \%)$ of the respondents therefore believed that life staging stimulates learners' imaginations and practice their abilities of communication and listening in an enjoyable process. Brash and Warnecke, (2009) for example pointed out that drama-based role play has positive effects on learners' communicative and affective skills as it stimulates the learners' authentic conversation and allows them to act in a framework, so they can overcome their fear of certain emotional, linguistic or social constraints.

Similarly, 16(53.3\%) teachers agreed with the statement that they prefer teaching English set-books using lifestaging technique since students understand better and are not bored. $9(30.0 \%)$ teachers strongly agreed with the statement while $5(16.7 \%$ ) teachers were in disagreement with the statement. The study further found out that majority $(83.3 \%)$ teachers preferred using life-staging technique as they view that through life staging, the students understand better and are not bored with the lessons. This supports the work of Zyoud, (2007) who pointed to the benefits of drama such as bringing enjoyment to lessons and increasing students' positive learning experiences.

The above findings showed that teachers of English had a positive attitude towards life-staging of set-books as most of them practiced. This is in contrast with stinson's views who states that in-service teachers in Singapore viewed drama as a trick to enliven lessons and a departure from the direct teaching and worksheets that were their normal practice (Stinson, 2009).

On interviewing HODs, it emerged that teachers of English had a negative attitude towards life-staging technique as a teaching methodology. This is attributed to the fact that life-staging of set-books consumes a lot of time during the teaching process. 


\section{Conclusions and Recommendations:-}

The aim of this study was to establish the perception of English language teachers on use of life-staging technique on English language teaching in Public secondary schools in Wareng Sub-County Uasin-Gishu County. The study concluded that teachers had a positive aatiitude towards the use of life-staging as a teaching strategy in schools. This was based on the fact that the teaching strategy enabled them achieve the set objectives, use of life staging enabled learners to understand the exploration of text, through life staging learners were able to acquire the necessary skills in English and therefore improve on their performances. The study recommended that teachers need to use learnercentered approaches during life staging since improve on learning outcomes of the learners.

\section{References:-}

1. Baldwin, P. (2012). With Drama in Mind: Real Learning in Imagined Worlds (2 ${ }^{\text {nd }}$ ed.). London: Continuum International Publishing Group.

2. Barasa P.L. (2005). English language teaching in Kenya: Policy, training and practice. Eldoret: Moi University press.

3. Brash, B., \& Warnecke, S. (2009). Shedding the ego: Drama-based role-play and identity in distance language tuition. Language Learning Journal, 37(1), 99-109.

4. Gudu, B. E. (2010). A survey of the 2002 integrated Approach to instruction to speaking skills in English. A case of selected Secondary Schools in Eldoret Municipality, (Unpublished M. Phil thesis). Eldoret: Moi University.

5. Hinkel, E. (2004). Teaching academic ESL writing: Practical techniques in vocabulary and grammar. Mahwah, NJ: Lawrence Erlbaum.

6. Jaiharn, P. (2003). The Comparison in English Speaking Ability for Communication and Motivation in Learning English for Seven Grade Students by Using Dramatic Activities and Non-Dramatic Activities. Master Theses. Graduate School of Silapakorn University.

7. Janudom, R., \& Wasanasomsithi, P. (2009). Drama and questioning techniques: Powerful tools for the enhancement of students' speaking abilities and positive attitudes towards EFL learning. ESP World, 8(5), 117.

8. Jeruto, Z. B. (2006). Factors affecting teaching and learning of poetry in integrated English syllabus. A case of selected schools in Nandi North District, (Unpublished M.phil Thesis). Eldoret: Moi University.

9. Karengo, M. (2007). Literature students. Daily Nation, Nation Printers, Nairobi

10. Kemboi, J \& Osman, A (2015). Role-Play Technique as an Antecedent of Performance in English Language: Evidence from Secondary Schools in Wareng District, Uasin Gishu County, Kenya. Journal of Education and Practice 6 (5),119-124.

11. Khaemba P. S (2004). The role of drama in the development of communicative competence among primary school pupils in Nakuru Municipality, (Unpublished M.phil thesis). Nairobi: Kenyatta University.

12. Kothari, C. R., (2008). Research Methodology: Methods and Techniques. (2 ${ }^{\text {nd }}$ Ed). Age, New Delhi, International publishers.

13. Maig (2014). Use of drama techniques as a methodology to teach English in infant education by teachers in catalonia. Retrieved on 2/2/2016 from ripostori.uvic.cat/bitsrewam/handle/10854/311/treau.2014.ulldemnolinscarla-use-dramatechnqiuesbdf.

14. Maley, A. \& Duff, A. (2001). Drama techniques in language learning: a resource book for communication Activities for language teachers. Cambridge: Cambridge University Press.

15. Moore, N., (2006). How to do Research: a practical guide to designing and managing research projects. (Third revised edition). London: Kongan page limited.

16. Moseti, P. (2007). Teaching / learning strategies in integrated English course and their effect on performance in Manga division Nyamira district, (Unpublished M.E.D Thesis). Nairobi: Kenyatta University.

17. Mutai, N., (2012). An assessment of the Teaching Strategies Employed by English Language Teachers in Eldoret municipality Kenya. Unpublished mphil Thesis. Eldoret: Moi University.

18. Nawi, A. M (2014). Applied Drama in English Language Learning. Unpublished Doctoral Thesis, University of Canterbury, New Zealand.

19. Ngaroga, J.M., (2006). Revision Education for Primary Teacher Education. Nairobi: Acts press.

20. Orodho, J. A. (2009). Elements of Education and Social sciences Research Methods. Maseno, Kenya: Kanezja Publishers. 
21. Panyaruang, B. (2012). The Study of Creative Dramatic Activities for Ability Re-enforcement in Speaking and Writing in English and Motivation of Classical Dramatic Arts. Master Thesis. Graduate School of Chiengmai University.

22. Royka, J. (2002): Overcoming the Fear of Using Drama in English Language Teaching. In: The Internet TESL Journal 8/6.

23. Stinson, M (2009). Drama is like reversing everything': intervention research as teacher professional development. Research in Drama Education4(2), 225-243.

24. Sulaiman, A. (2013). Using Educational Drama and Role-playing. Teaching English in Gaza Governorates. Gaza: The Islamic university of Gaza.

25. Ulas, A. H. (2008). Effects of creative educational drama on developing oral skills in primary school children. American Journal of Applied Sciences, 5(7), 876-880.

26. Zyoud, M.M (2016). Using Drama Activities and Techniques to Foster Teaching English as a Foreign Language: A Theoretical Perspective. Al Quds Open University. 